Meta

Journal des traducteurs

Translators' Journal

\title{
Literary Translation in Nigeria
}

\section{Unionmwan Edebiri}

Volume 28, numéro 1, mars 1983

La traduction dans le monde

Translation around the World

URI : https://id.erudit.org/iderudit/002694ar

DOI : https://doi.org/10.7202/002694ar

Aller au sommaire du numéro

Éditeur(s)

Les Presses de l'Université de Montréal

ISSN

0026-0452 (imprimé)

1492-1421 (numérique)

Découvrir la revue

Citer cet article

Edebiri, U. (1983). Literary Translation in Nigeria. Meta, 28(1), 27-34.

https://doi.org/10.7202/002694ar

Ce document est protégé par la loi sur le droit d'auteur. L'utilisation des services d'Érudit (y compris la reproduction) est assujettie à sa politique d'utilisation que vous pouvez consulter en ligne.

https://apropos.erudit.org/fr/usagers/politique-dutilisation/
Cet article est diffusé et préservé par Érudit.

Érudit est un consortium interuniversitaire sans but lucratif composé de l’Université de Montréal, l'Université Laval et l'Université du Québec à Montréal. Il a pour mission la promotion et la valorisation de la recherche. https://www.erudit.org/fr/ 


\section{LITERARY TRANSLATION IN NIGERIA}

UNIONMWAN EDEBIRI

Translation has been going on in Nigeria for over a hundred and thirty years now. It started as an offshoot of missionary activity in the country. When the missionaries launched into earnest evangelisation in Nigeria in the wake of British conquest, it quickly dawned on them that the availability of the Bible in the local languages would facilitate their work. But the absence of a written tradition in the indigenous languages was a major stumbling block. Even the northern parts of the country, islamized in the $14^{\text {th }}$ century, could boast of writing only in Arabic and not in any of the local languages. The missionaries then proceeded to establish orthographies for some of the local languages and translate the Bible into them. By the middle of the last century, the Bible had been rendered into Yoruba, Igbo, Hausa, Efik, Ijaw and Kanuri, mainly through the efforts of Samuel Ajayi Crowther, S. A. Allen, V.B. Vincent, J.F. Schon, S.W. Koelle, J.C. Taylor and W.E.L. Carew, all of whom belonged to the Church Missionary Society. Thus, it can be said that the Church Missionary Society (C.M.S.) pioneered translation in Nigeria.

About the same time, some missionaries also showed interest in translating aspects of Nigerian indigenous literatures into English. In 1854, S.W. Koelle published his African Native Literature, containing Kanuri proverbs, tales, fables and historical fragments ${ }^{1}$. His initiative was followed twenty-one years later by J.F. Schon who, in 1885, published Magana Hausa, a book of Hausa proverbs, tales and fables ${ }^{2}$. African Native Literature and Magana Hausa were the earliest recorded literary translations in Nigeria. Thus, in Nigeria, whereas translation per se began by the rendering of the Bible from English into indigenous languages, literary translation started in the opposite direction, that is, from indigenous languages into English.

In the course of time, a host of foreign ethnographers and colonial administrators joined in the translation of folktales from various Nigerian languages into English. In later years, expatriate members of staff of Nigerian institutions of education also engaged in translating indigenous literatures into English. Notable among these are Robert G. Armstrong who has rendered a large corpus of Idoma folk literature into English and Ulli Beier who has done a remarkable job in translating many Yoruba literary texts into English. Mention should also

1. London, Society for Promoting Christian Knowledge.

2. Id. 
be made of Mervin Hiskett who put into English the famous novel, Shehu Umar, written originally in Hausa, by the late Prime Minister of Nigeria, Tafawa Balewa $^{3}$.

In recent years, a number of Nigerian scholars have also embarked on literary translation from indigenous languages into English. These include two of Nigeria's foremost writers, J.P. Clark who translated the monumental Ijaw legend of Ozidi into Ozidi Saga and Wole Soyinka who rendered Fagunwa's novel : Ogboju ode ninu igbo irunmale into The Forest of a Thousand Demons ${ }^{4}$; others are Wande Abimbola, the translator of the original Ifa divining corpus ${ }^{5}$ and Romanus Egudu and Donatus Nwoga, the joint translators of Poetic Heritage: Igbo Traditional Verse, a book in the Unesco translated literature series ${ }^{6}$. Egudu has also published The Calabash of Wisdom and Other Igbo Stories, a collection of Igbo folktales ${ }^{7}$. Some promising young academics, such as Nnabuenyi Ugonna and Fred Akporobaro, have also been involved in literary translation. Ugonna has translated some Igbo verses and tales into English, a task which Akporobaro has performed for Isoko tales, poems and proverbs ${ }^{8}$.

Among Nigerians who have translated traditional lore into English, Adeboye Babalola, Oteikwu Amali and Elohon Osemwingie belong to a category all of their own. Each of them is a writer in his own right in his native language; Babalolain in Yoruba, Amali in Idoma and Osemwingie in Edo. Consequently, each translates into English not only the folk literature in his own language but also his own writings as well. Adeboye Babalola is best known for his translation (and study) of Ijala, the traditional poetry of Yoruba hunters ${ }^{9}$. Although some of his poems have appeared in translations, Amali has published a bilingual (Idoma-English) play: Onugbo Mloko ${ }^{10}$. Osemwingie's translations of Edo praise songs has attracted critical attention ${ }^{11}$. Babalola, Amali and Osemwingie have also published English translations of their own poems as well as other creative writings. Only these three and Soyinka have translated into English contemporary literature written in indigenous languages.

From the foregoing remarks, it is obvious that the emphasis in literary translation in Nigeria has so far been on the rendering of traditional or oral literatures into English. This is no doubt a worthwhile undertaking. Indeed, there is an urgent necessity to retrieve our oral literatures from oblivion before the old who know them best pass away, for as the Malian author, Hampate $\mathrm{Ba}$, rightly stated, "when an old man dies in Africa, it's like a whole library burnt down" "12. It is also precisely for this reason that Africans generally enthuse

3. London and Harlow, Longmans, 1967.

4. London, Nelson, 1965.

5. Sixteen Great Poems of Ifa, Paris, Unesco, 1975 and Ifa Divination Poetry, New York, London and Lagos, NOK Publishers Limited, 1977.

6. Enugu, Nwankwo - Ifejika \& Company (Publishers) Limited, 1971.

7. New York, London and Lagos, NOK Publishers Limited, 1973.

8. Cf. Black Orpheus, Vol. 3, No. 4, Dec. 1976, p. 6-10.

9. The Content and Form of Yoruba Ijala, London and New York, O.U.P., 1966.

10. University of Ibadan, Institute of African Studies occasional publication, No. 30, 1974

11. Cf. Cultural Heritage of Benin, Benin City, Midwest Newspapers Corporation, 1972, p. 136-141.

12. Quoted by Jacques Chevrier (1974): Litérature nègre, Paris, Armand Colin, p. 233. The translation is mine. 
over the mere transcriptions and translations of aspects of their literary heritage and often make little or no attempt to assess the quality of such efforts.

Be that as it may, it should not be forgotten that there are lots of creative writings today in indigenous languages which are yet to be translated either into English or Nigerian languages other than those in which they are written. This explains why Nigerian writers in indigenous languages like Kontagora, Abdukarim Zakari, Saadu Zungur (Hausa), D. O. Fagunwa, I.O. Delano, Afolabi Olabintan (Yoruba), Pita Nwana, T. U. Ubesi and J.C. Madueke (Igbo) and Ernest Edyang, Elizabeth Asibong and E.N. Amaku (Ifik) are known only to speakers of their respective languages. Some of their writings certainly deserve to be made available in translations to the Nigerian public at large.

Similarly, efforts should be made to translate Nigerian literature in English into local languages. In terms of quantity, this literature is the most significant in the black world. In quality, it has won considerable international critical admiration. In fact, the works of the most successful of Nigerian creative writers - Chinua Achebe, Wole Soyinka, J.P. Clark and Cyprian Ekwensi are read all over the world not only in their English originals but also in translations in several languages. Yet none of their writings, to my knowledge, has been translated into any Nigerian language. The result is that at home these world-famous Nigerian authors are read only by an infinite minority of their compatriots. Yet their works are heavily indebted to indigenous languages and cultures. As Albert Gerard has observed, "creative writing in Africa today is still strongly influenced by the literary traditions of the past in both form and content" ${ }^{13}$. More specifically, Emmanuel Obiechina has stated that

whether in the tales of Amos Tutuola, in the novels of Achebe, in the plays of Clark and Soyinka or in the poems of Okigbo, ... the writers are drawing elaborately from West African folklore, traditional symbols and images, and traditional turns of speech, to invest their writings with a truly West African sensibility and flavour ${ }^{14}$.

It is important at this point to underline the error often committed in defining Nigerian literature as consisting only of Nigerian creative writings in English. In a multilingual country like Nigeria which produces literature in more than one language, it is probably more appropriate to speak of Nigerian literatures than Nigerian literature. Nigerian literatures are not just works written in English by Nigerians; they are the corpus of literary works produced by Nigerians, embracing both oral and written literatures, in indigenous languages as well as in English.

The literatures in the various indigenous languages in the country have a crucial role to play in forging a Nigerian national cultural identity. Adeboya Babalola makes the point in the following remark:

English language and literature cannot well serve the purpose of fostering national cultural identity. The truth of the matter is that Nigerian languages and literatures, being themselves a dominant part of the cultures of Nigeria, are the right machinery for doing the job of fostering this identity ${ }^{15}$.

13. "Preservation of Tradition in African Creative Writing", Research in African Literatures, Spring 1970 , Vol. 1, No. 1, p. 39.

14. "Transition from Oral to Literary Tradition", Présence africaine, No. 63, p. 143.

15. "The Role of Nigerian Languages and Literatures in Fostering National Cultural Identity", Présence Africaine, No. 94, p. 83. 
Certainly, exposure to the same literatures can help to forge the highly desirable national cultural identity in Nigeria. But this national cultural identity is inconceivable in Nigeria without literary translation, for it is only through literary translation that the literatures in the different languages can be made available to the Nigerian public at large. Admittedly, as we have earlier observed, the majority of Nigerians are not even literate in their own languages.

But it is equally true that the availability of reading materials in the indigenous languages can generate a keen interest in these languages and create a large readership in them. If the usefulness to Nigerians of these literatures in the local languages is not in doubt, then the radio and television can be used to bring them to those Nigerians who may not make the effort, or who may not be able, to read them. This is already being done to a limited extent but it needs to be intensified. Nigerians certainly do appreciate good poetry or plays in the local languages when broadcast over the radio or shown on television. Such works will even be more satisfying and meaningful to them than the cultural alienating foreign texts with which they are so frequently and indiscriminately bombarded.

This is not to imply that the Nigerian public should be denied access to foreign literary works; the Nigerian public should have free access to foreign literary texts of recognizable and indisputable merit. Indeed, it should be exposed, not to foreign texts of inferior quality as it is often the case, but to the classics of world literature. These can help to nourish the literatures in indigenous Nigerian languages since Nigerian writers may borrow some thematic elements and stylistic devices from them.

Thus, there is a great need for literary translation in Nigeria from English and other foreign languages into Nigerian indigenous languages but more particularly from one indigenous Nigerian language into another. Unfortunately, some factors militate against it. The first major obstacle is, in fact, that most educated Nigerians are themselves not fluent in the written forms of the indigenous languages. This is hardly surprising. Indigenous languages were relegated to the background in the curriculum of the educational system introduced and operated by the British colonial master. Until the dying years of British colonial rule, Nigerians did not have the opportunity of studying their own languages beyond the primary school level. Even in the primary school, by far fewer hours were devoted to them than to English which, in addition, was the language of instruction and therefore compulsory in every school. In fact, a failure in English usually meant a failure in an examination as a whole. Thus, in the school system, English had an overriding importance: it could virtually enhance or mar the educational progress of the pupil.

This was not all. As the language of the colonial master, English also enjoyed tremendous prestige outside the school system. It actually had an important role to play in determining the professional success or advancement as well as the social status of the individual in the country. Consequently, Nigerians felt compelled to pay more attention to it than to their own languages. As a result, educated Nigerians could hardly speak their own languages without interspersing them with some English words or phrases. Worse still, they did not 
generally match their oral ability with a corresponding scribal competence in the indigenous languages.

In fact, it is probably more correct to say that most educated Nigerians cannot even write in their indigenous languages. This situation has not changed much since independence. However, Nigerians now have the opportunity if they are so inclined, to study up to university such indigenous languages as Hausa, Yoruba, Igbo and Edo. It is to be expected that, as more Nigerians graduate in the indigenous languages, it will be possible to undertake more literary translations from and into these languages.

The other significant problem facing literary translation in Nigeria arises from the fact that translation per se is not yet an established profession in Nigeria. Although the status of the indigenous languages, which we have just evoked, is partly responsible for this, the main reason is that qualified translators are still few in Nigeria. This, in turn, is due to the fact that the British colonial master did not encourage the teaching in the country of any foreign modern language other than his own. Consequently, it was not until after independence in 1960 that modern languages began to be studied to a degree level in the country. In fact, Nigeria's premier university, the University of Ibadan, established in 1947, turned out its first graduate in French only in 1965, the same year as the University of Nigeria at Nsukka, founded in 1960, produced eleven graduates in modern languages (French and Russian or French and German)!

These graduates as well as those of the late 60 's were employed mostly either as teachers in the secondary schools or as administrative or external affairs officers in the civil service. None of them was employed as a translator although they could be called upon, whenever the need arose, to do some translations. This was so because the authorities did not feel that the country needed the services of full-time translators. However, by 1970, the importance of translation services had become apparent in view of the country's expanding international relations and obligations.

The need became so pressing that, in 1971, the Federal Government embarked upon a crash programme to train its own corps of translators. Fresh graduates of modern languages were recruited and sent abroad (Canada, France, Germany, Russia, China, etc.) to train as professional translators. On qualifying, they were deployed to various ministries in the federal civil service where bleak career prospects and insufficient remuneration soon compelled many to resign and seek more rewarding jobs in international organisations or even as freelance translators. Their experience has not helped in making translation and attractive profession in the country.

However, translation in general seems to have a bright future in Nigeria. Its future depends largely on the translators themselves. They seem to realise this and have decided to come together to fight for their profession. In this regard, the establishment last February (1981) of the Nigerian Association of Translators and Interpreters (NATI) augurs well for the profession in Nigeria.

It needs to be stressed that as far as literary translation is concerned, the Federal and State Governments, the Universities and the Publishers' Association of Nigeria have an important role to play in its development in Nigeria. 
First and foremost, it is the responsibility of the Federal Government to grant official recognition to NATI if it deems it so qualified. Such a status will enable it to enjoy the prerogative of similar professional bodies in the country. It will also entitle it to be consulted by government in all matters affecting the practice of translation in the country. It is during such consultations that NATI can negotiate better conditions of service or career prospects for professional translators employed in the public service of the country. It must be remembered that lack of clearly defined career prospects and inadequate remunerations caused the massive resignations of the first batches of translators trained by the federal government.

In addition, official recognition of NATI as a professional body will confer on it the legal right to regulate the practice of professional translation in Nigeria. In this way, the Association will be in a position to determine the qualifications for admission into the profession and thus ensure that translations done by its members are of acceptable standards.

Then, the federal and state governments can help in training literary translators and in providing them with jobs. All the governments of the Federation are keenly interested in developing indigenous Nigerian languages; while the Federal Government pays special attention to the three main languages of the country (Hausa, Yoruba and Igbo), the State Governments are concerned with the main languages in their States. Since the governments are bent on developing the local languages, NATI should not have much difficulty in convincing them that literary translation, by making more reading materials in other languages foreign and local - available to schoolchildren in their own languages, is indispensable to the success of their language policies.

Following from this, the Association should persuade the governments to make the training of literary translators a priority. This will involve automatic scholarship award to students specializing in literacy translation in States where free education is yet to become an official government policy.

Finally, the federal government should be urged to set up a unit at the National Language Centre to consider for publication in other Nigerian languages, books in local languages adjudged to be of national interest or great literary merit. At the State level, the government can create a similar unit in the State Arts Council.

Apart from the governments, the universities can contribute immensely to the growth of literary translation in Nigeria. At the moment, Nigerian Universities have not shown much enthusiasm in developing specialist courses in translation. Only the University of Ibadan seems to be offering a post-graduate course in Translation. The University of Lagos has a qualified staff to man a full department or, at least at the initial stage, a sub-Department of Translation. But financial restrictions have so far not allowed the creation of a Department of Translation in either of these institutions. It will be the duty of NATI to press for the establishment (as a matter of urgency) of one full-fledged Department of Translation in at least one Nigerian University.

Also, in most Nigerian Universities, students of Nigerian languages or English collect and transcribe into English aspects of the traditional literature in 
their respective languages, as part of the requirements for their bachelor's degree. Most of the transcriptions rust away in lockers and are hardly consulted afterwards. Yet some of them are of good quality. NATI should urge each University to have such good quality transcriptions refurbished by competent or professional translators and published by the University Press. The chances of its successfully persuading the Universities to do this seem bright in view of the fact that University Presses in Nigeria are not essentially profit-oriented. Similarly, NATI should encourage other Institutes of African Studies in Nigerian Universities to follow the example of the Institute of African Studies of the University of Ibadan which, for some years now, has been sponsoring the translation of various aspects of Nigerian oral literature into English.

Then, NATI should persuade the Universities to adopt a policy of providing space for literary translations in their journals devoted to the Humanities. Black Orpheus, now published by the University of Lagos, contains from time to time literary translations from Nigerian indigenous languages into English. It should be possible to publish in it as well as in other University journals translations from Nigerian literature in English into at least the three main languages of the country. In the same way, cultural journals published by the Federal or State government agencies like Nigeria Magazine (published by the Federal Ministry of Information) and Oduma (Published by the Rivers State Arts Councii) should also open up their columns to literary translations, especially from English into indigenous languages.

Finally, the Association will have to deal with the Publishers' Association. It is obvious that publishers are out to make profit. They are therefore interested in books which offer bright prospects of commercial success. NATI should be able to recommend to publishers good materials for translation and even the best translators to undertake particular translations. In a case where the cost of publishing or translation may be somewhat prohibitive, NATI, in conjunction with the Publisher's Association, should seek a government subsidy for the project. Then, to ensure a constantly good quality translation, NATI should persuade publishers through their Association to accept the principle of having translations done for them cross-checked by at least another expert before publishing them.

It goes without saying that only a very influential NATI can deal effectively with the three bodies - the Federal and State governments, the Universities and the Publishers' Association - whose support and co-operation are crucial to the growth of literary translation in Nigeria. It is no less obvious that NATI will derive its influence from its dynamism and respectability which, in turn, will depend not just on the size and calibre of its membership but also on its activities. Consequently, NATI should :

$i$. grant its membership only to appropriately trained and qualified translators;

ii. strive to ensure a high standard of translation by its members.

The Association can best do this by :

$i$. imposing strict sanctions on members who turn out careless translations;

ii. awarding annual prizes to the best literary translators in each year. 
iii. establishing a newsletter or journal which will publish reviews of literary translations undertaken by its members and articles dealing with general problems of translation and translation criticism.

NATI seems determined to work along these lines. Its successful execution of its programmes will no doubt be used in a rosy future for literary translation in Nigeria. 